\title{
Ultradian, circadian and seasonal rhythms in cortisol secretion and adrenal responsiveness to ACTH and yarding in unrestrained red deer (Cervus elaphus) stags
}

\author{
J R Ingram ${ }^{\mathbf{1}, \mathbf{2}}$, J N Crockford ${ }^{\mathbf{1}}$ and L R Matthews ${ }^{\mathbf{1}}$ \\ ${ }^{1}$ Animal Behaviour and Welfare Research Centre, AgResearch, Private Bag 3123 Hamilton, New Zealand \\ ${ }^{2}$ Biology Department, University of Waikato, Private Bag 3105 Hamilton, New Zealand \\ (Requests for offprints should be addressed to J R Ingram, Animal Behaviour and Welfare Research Centre, AgResearch, Private bag 3123 , Hamilton, \\ New Zealand)
}

\begin{abstract}
Seasonal changes in the activity and responsiveness of the adrenal gland in red deer (Cervus elaphus) stags were quantified by measuring $24 \mathrm{~h}$ endogenous cortisol secretory profiles and plasma cortisol responses to either administration of exogenous ACTH or a standardised stressor during November (period of velvet growth), February (pre-rut), April (mid-rut) and July (post-rut) (southern hemisphere) using a remote blood sampling device (DracPac).

Ultradian rhythms in the concentration of plasma cortisol were observed resulting from the episodic secretion of cortisol from the adrenal cortex at a mean rate of 0.8 pulses $/ \mathrm{h}$. Circadian rhythms in plasma cortisol concentrations were also found in 11 out of the 20 complete $24 \mathrm{~h}$ profiles (mean amplitude, $3 \cdot 8 \pm 1 \cdot 4 \mathrm{ng} / \mathrm{ml})$.

Seasonal rhythms in mean $24 \mathrm{~h}$ plasma cortisol concentrations and cortisol pulse parameters were also observed. Mean $24 \mathrm{~h}$ plasma cortisol concentrations were higher in November $(12.5 \pm 1.0 \mathrm{ng} / \mathrm{ml})$ than in February $(6 \cdot 3 \pm 1 \cdot 0 \mathrm{ng} / \mathrm{ml})$, April $(4 \cdot 0 \pm 1 \cdot 0 \mathrm{ng} / \mathrm{ml})$ or July $(4 \cdot 2 \pm 1 \cdot 0 \mathrm{ng} / \mathrm{ml})$. Cortisol pulse height, nadir and
\end{abstract}

amplitude were all significantly higher in November than at other times of the year $(P<0 \cdot 01)$.

Peak cortisol concentrations following infusion of ACTH $_{1-24} \quad\left(0.04 \mathrm{IU} \mathrm{kg}^{-1}\right)$ were higher $(P<0 \cdot 05)$ in November $(55.8 \pm 2.7 \mathrm{ng} / \mathrm{ml})$ and lower $(P<0.001)$ in April $(33.7 \pm 1.8 \mathrm{ng} / \mathrm{ml})$ than those in February and July $(48 \cdot 7 \pm 2 \cdot 0 \mathrm{ng} / \mathrm{ml}$ and $45 \cdot 4 \pm 2 \cdot 0 \mathrm{ng} / \mathrm{ml}$ respectively). The area under the cortisol response curve was significantly smaller $(P<0 \cdot 05)$ in April $(266.6 \pm 15.3 \mathrm{ng} / \mathrm{ml} /$ $190 \mathrm{~min}$ ) than at other times of the year (February, $366 \cdot 1 \pm 15 \cdot 3 \mathrm{ng} / \mathrm{ml} / 190 \mathrm{~min} ; \mathrm{July}, 340 \cdot 7 \pm 15 \cdot 3 \mathrm{ng} / \mathrm{ml} /$ $190 \mathrm{~min}$ and November, $387 \cdot 8 \pm 21 \cdot 2 \mathrm{ng} / \mathrm{ml} / 190 \mathrm{~min}$ ).

These data demonstrate that the adrenal gland of the red deer stag exhibits ultradian, circadian and seasonal rhythms in activity, and that its responsiveness to ACTH varies with season. November, a period of reproductive quiescence in the southern hemisphere, with new antler growth and rapid weight gain, is associated with higher mean plasma cortisol concentrations and a greater responsiveness to exogenous ACTH. In contrast, the breeding season is associated with lower adrenal activity and responsiveness. Journal of Endocrinology (1999) 162, 289-300

\section{Introduction}

Changes in the activity and function of the hypothalamicpituitary-adrenal (HPA) axis are routinely used to assess welfare in farm animals (Barnett \& Hemsworth 1990, Fraser \& Broom 1990). Studies in a variety of species including human (Veldhuis et al. 1990), cattle (Ladewig \& Smidt 1989), sheep (Kennaway et al. 1981) and deer (Monfort et al. 1993) have shown that the HPA axis exhibits variations over time in basal activity and responsiveness, distinct from that following the imposition of a stressor. This variation can form a consistent rhythm which fluctuates within or about $24 \mathrm{~h}$ (ultradian and circadian rhythms respectively) or can be of longer duration, with variations occurring on an annual basis (seasonal or circannual rhythms).

Ultradian rhythms in plasma concentrations of glucocorticoids are the result of episodic secretion of glucocorticoid pulses from the adrenal cortex. Such pulsatile secretion is thought to prevent down-regulation of the HPA axis while maintaining its ability to respond to stress (Monfort et al. 1993). In deer, episodic secretion of cortisol, the predominant glucocorticoid (van Mourik et al. 1985, Smith \& Bubenik 1990), has been investigated in Eld's deer (Cervus eldi thamin) (Monfort et al. 1993) but there appears to be no information on cortisol secretory dynamics in red deer (Cervus elaphus). 
Circadian rhythms in plasma glucocorticoid concentrations are well characterised for humans (Weitzman et al. 1971) and rodents (Keller-Wood \& Dallman 1984), with peak concentrations preceding the activity phase of the daily cycle. This rhythm is entrained by feeding (Saito et al. 1989) and activity/sleep wake cycles (Born et al. 1997). There is no evidence from studies of deer for a circadian rhythm in HPA axis activity (white-tailed deer (Odocoileus virginianus) (Bubenik et al. 1983); rusa deer (Cervus timorensis) (van Mourik \& Stelmasiak 1984); Eld's deer (Monfort et al. 1993)). However, in these studies the deer were subjected to either handling or indoor housing, factors known to attenuate circadian rhythms in other species (Irvine \& Alexander 1994).

Seasonal changes in activity and responsiveness of the HPA axis have been reported in a number of species including humans (Walker et al. 1997), primates (Schiml et al. 1996), rodents (Boswell et al. 1994) and fish (McLeese et al. 1994). Evidence for a seasonal rhythm in adrenal activity or responsiveness in deer varies between species and studies, with seasonal changes reported in white-tailed deer (Bubenik et al. 1983), reindeer (Rangifer tarandus) (Nilssen et al. 1985), axis deer (Axis axis) (Chapple et al. 1991) and red deer (Suttie et al. 1995, Cassidy 1996) but not in Eld's deer (Monfort et al. 1993) or in another study on axis deer (Bubenik \& Brown 1989).

Red deer stags undergo dramatic seasonal changes in physiology and behaviour associated with the breeding season (rut). These include changes in secretion of hormones involved in the reproductive (Lincoln \& Kay 1979, Suttie et al. 1992) and growth and metabolic (Suttie et al. 1989) axes. Changes in behaviour at this time include increased aggression (Suttie 1985) and a reduced voluntary food intake (Loudon et al. 1989) resulting in pronounced weight loss (Kay 1979). It is well documented in other mammalian species that HPA axis activity can be modulated by changes in reproductive function (increased activity and responsiveness in castrates compared with entire males (Bass et al. 1982, Verkerk \& Macmillan 1997)) and changing metabolic and growth demands (Yanovski et al. 1997) as well as by social factors (Lyons et al. 1988). This has yet to be demonstrated for red deer.

Changes in responsiveness of the HPA axis as assessed by the adrenal response to physiological (e.g. adrenocorticotrophin (ACTH) infusion, insulin induced hypoglycaemia) or psychological (e.g. handling, open field test) challenges are commonly used in assessing the normal functioning of the HPA axis in animal stress research. Seasonal changes in adrenal responsiveness to ACTH challenge have recently been demonstrated in red deer stags (Suttie et al. 1995, Cassidy 1996) but there have been no studies of seasonal variation in response to stress or basal activity of the HPA axis.

The aim of the current study was to identify and quantify ultradian, circadian and seasonal rhythms in basal cortisol secretion of red deer stags. In addition, we sought to measure seasonal changes in adrenal and HPA axis responsiveness following challenges with $\mathrm{ACTH}$ and a standardised management stressor.

Routine handling of red deer (e.g. yarding, drafting and restraint) has been shown to result in activation of the HPA axis (Ingram et al. 1994, 1997, Carragher et al. 1997). To avoid the confounding effects of handling stress on basal HPA axis activity, a remote blood sampling device (Ingram et al. 1994) was used to obtain blood samples from undisturbed animals at pasture.

\section{Materials and Methods}

\section{Animals}

Twelve 3-year-old red deer stags were maintained at the Ruakura Agricultural Centre, Hamilton, New Zealand $\left(37^{\circ} 46^{\prime} \mathrm{S}, 175^{\circ} 20^{\prime} \mathrm{E}\right)$. Two groups of 6 animals, balanced for weight, were formed in July 1995. Each group was kept in a separate 0.25 hectare paddock during the experiment and in $0 \cdot 25-0 \cdot 5$ hectare paddocks between experiments, with free access to pasture (ryegrass-white clover) and water.

\section{Procedure and remote blood sampling}

On four separate occasions throughout the year (1/11/95, 7/2/96, 10/4/96 and 10/7/96), blood samples were collected from the same three animals in each group over a $24 \mathrm{~h}$ period ( $24 \mathrm{~h}$ profile) and following two types of challenge (ACTH and yarding). Animals from two separate groups were used so that data were obtained from two replicates, thereby reducing the chances that features unique to one group would influence the results obtained. The experimental procedure was similar for each season, as detailed below.

On day 1 all animals were weighed and the animals to be blood sampled were sedated with an i.m. injection of $1 \mathrm{mg} \mathrm{kg}{ }^{-1}$ xylazine hydrochloride (Rompun, Bayer, Auckland, NZ) and a modified double lumen catheter (Cavafix Duo16/18G $32 \mathrm{~cm}$, B. Braun, Melsungen, Germany) (see Fig. 1) was inserted into the jugular vein. At the same time all cannulated animals were fitted with a canvas and leather backpack. Sedation was reversed with an i.v. injection of $0.25 \mathrm{mg} \mathrm{kg}^{-1}$ yohimbine hydrochloride (Revercyl, Aspiring Animal Services Ltd, Wanaka, NZ) and the animals were then reunited with the remaining three animals in their group and returned to their respective paddocks.

The following day (day 2) the $24 \mathrm{~h}$ profile blood samples were collected. Both groups were penned between 0600 and $1030 \mathrm{~h}$ and each of the six experimental animals was fitted with a battery powered remote blood sampling device (DracPac, Engineering Development Group, HortResearch and ABWRC, AgResearch, Ruakura Agricultural Centre, Hamilton, NZ). 


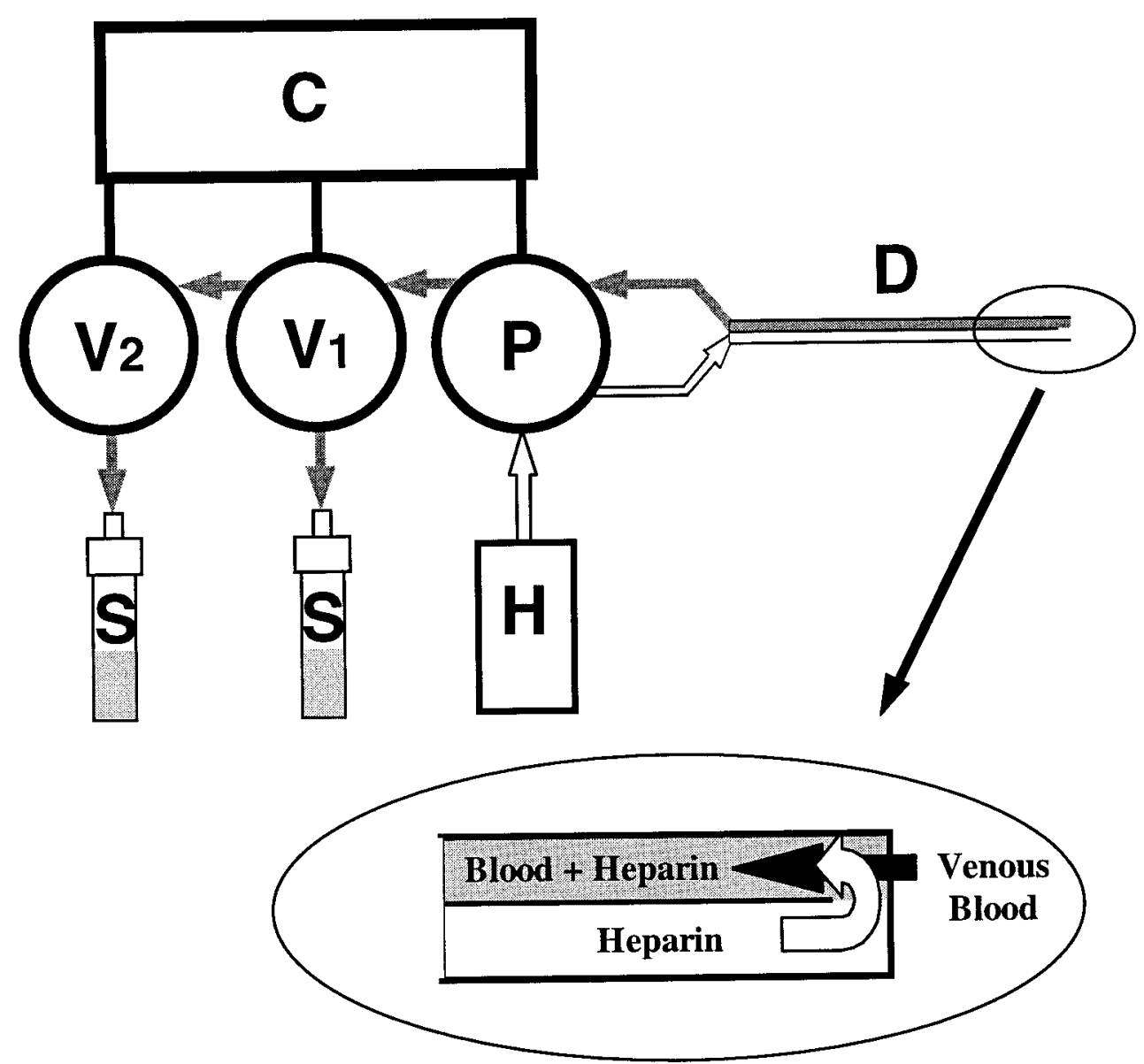

Figure 1 Schematic representation of the DracPac remote blood sampling system used for automatic continuous sampling of blood from free ranging animals. The device comprises: a microprocessor control box $(C)$, a peristaltic pump unit $(P)$, a plastic bag containing concentrated heparin $(H)$, two 38-port rotary switching valves $\left(\mathrm{V}_{1-2}\right), 74$ separate blood collection tubes $(\mathrm{S})(4.5 \mathrm{ml}$ monovette syringe $)$ and a double lumen catheter (D) (Cavafix Duo16/18G $32 \mathrm{~cm}$ ) which is modified by shortening the end of the catheter by $\sim 5 \mathrm{~cm}$ and removing $1-2 \mathrm{~mm}$ of the wall between the two lumina at the tip to facilitate optimal mixing of the outflowing heparin and inflowing blood (see Ladewig \& Stribrny 1988).

The DracPac device (Fig. 1) consists of a pump unit containing two small peristaltic pumps for pumping heparin and drawing blood (length $150 \mathrm{~mm}$, diameter $50 \mathrm{~mm}$, weight $395 \mathrm{~g}$ ), two 38-position rotary switching valves (length $200 \mathrm{~mm}$, diameter $60 \mathrm{~mm}$, weight $950 \mathrm{~g}$ ), a 6 volt battery supply (Duracel, MN908) and a control box (length $160 \mathrm{~mm}$, width $80 \mathrm{~mm}$, height $60 \mathrm{~mm}$, weight $580 \mathrm{~g})$ containing a programmable microprocessor which allows programming of the start time, duration and rate of sample collection. The heparin pump delivers heparinised saline $(5000 \mathrm{IU} / \mathrm{ml})$ down one side of the double lumen catheter to the tip where it mixes with jugular blood being continuously drawn up the second lumen by the action of the blood pump. Heparin was delivered at a rate of $1.1 \mathrm{ml} / \mathrm{h}$ on days $2-3$ and $2.6 \mathrm{ml} / \mathrm{h}$ on day 4 . The heparinised blood passed through one or both rotary switching valves and was collected into 1 of 74 separate blood collection tubes $(4.5 \mathrm{ml}$ monovette syringe, Sarstedt Ltd, Numbrecht, Germany). The samples were stored on ice pads (Dry Chill, Warragul, Vic., Australia) in an insulated pouch within the backpack. Cortisol concentrations remain stable in heparinised whole blood samples collected from red deer and stored in this fashion for at least $24 \mathrm{~h}$ (J R Ingram, unpublished data). Cortisol concentrations are also stable in heparinised whole blood of cattle stored at room temperature for up to $72 \mathrm{~h}$ (Reimers et al. 1983).

The DracPac was programmed to pump blood to waste until $1400 \mathrm{~h}(3 \cdot 5 \mathrm{~h}$ after release from the yarding facility) to allow cortisol concentrations to return to baseline after handling (Ingram et al. 1994). The device was programmed to collect blood continuously at a rate of 
$15 \mathrm{ml}$ per hour for 74 samples, each of 20 min duration. Following collection of the last blood sample $(1440 \mathrm{~h}$ day 3), the animals were returned to the yards and the DracPac and blood samples were removed from the backpack.

On day 4, blood samples were collected before, during and after two types of challenge $\left(\mathrm{ACTH}_{1-24}\right.$ infusion and a yarding stressor). The 6 experimental animals were fitted with the remote blood sampling devices as on day 2 , and returned to their respective paddocks. The DracPacs were programmed to pump blood to waste until $1230 \mathrm{~h}(3 \cdot 5 \mathrm{~h}$ after release from the yarding facility), then to collect two $10 \mathrm{~min}$ baseline samples $(30 \mathrm{ml} / \mathrm{h})$. Immediately following the second baseline sample the DracPac was programmed to infuse $2 \mathrm{ml}$ physiological saline containing 0.04 IU $\mathrm{ACTH}_{1-24} / \mathrm{kg}$ live weight (Synacthen; Ciba NZ, Auckland, NZ) over 5 min into the jugular vein. Fresh blood was then drawn from the animal through the blood lines to a waste tube for $5 \mathrm{~min}$ to clear the blood lines of saline. Following the ACTH infusion and flushing of blood lines (total time $10 \mathrm{~min}$ ) eighteen $10 \mathrm{~min}$ blood samples $(30 \mathrm{ml} / \mathrm{h}$ ) were collected over $180 \mathrm{~min}$. Three hours after the ACTH challenge $(1600 \mathrm{~h})$ the animals were subjected to the yarding procedure. This comprised bringing the animals in their respective groups of six from their experimental paddocks into the yarding facility and keeping them in an indoor pen $(2.4 \times 2.4 \mathrm{~m})$ for $10 \mathrm{~min}$ before returning them to their paddock (total time from leaving the paddock, yarding and return to the paddock was $30 \mathrm{~min}$ ). Eight $10 \mathrm{~min}$ blood samples $(30 \mathrm{ml} / \mathrm{h}$ ) were collected during yarding and for 50 min subsequently at pasture. Following collection of the last blood sample, the experimental animals were returned to the yards and the catheter, blood samples and all equipment removed. A prophylactic dose of antibiotic (Tripen LA, Ethical Agents Ltd, Auckland, NZ) was administered i.m. after removal of the catheter. The experimental protocol was approved by the Ruakura Animal Ethics Committee.

\section{Plasma cortisol analyses}

All blood samples were centrifuged (1200 $\boldsymbol{g}$ for $15 \mathrm{~min}$ ) after removal from the backpacks and the plasma stored at $-20{ }^{\circ} \mathrm{C}$ until assayed for cortisol. Plasma cortisol concentrations were determined in duplicate, after extraction in ethyl acetate, by an ${ }^{125}$ I radioimmunoassay method with polyethylene glycol separation (Ingram et al. 1994). A standard curve, using charcoal stripped deer plasma, was constructed and used to determine the concentration of cortisol in individual plasma samples. The cross-reactivity of the antiserum with 11-deoxycortisol was $5 \cdot 7 \%$ and with cortisone was $1 \cdot 2 \%$. The mean inter- and intra-assay coefficients of variation for spiked deer plasma controls of known low, medium and high cortisol concentrations were $13 \cdot 1$ and $13 \cdot 8 \%$ respectively. Assay sensitivity was $0 \cdot 9 \mathrm{ng} / \mathrm{ml}$.

\section{Statistical analysis}

Pulse detection Discrete pulses in cortisol secretion were quantified using cluster analysis (Veldhuis \& Johnson 1986), a statistically based peak detection algorithm. A cortisol pulse was defined as a statistically significant increase in a cluster of cortisol concentrations which preceded a significant decrease. A cluster size of one point for the nadir and one point for a peak was used along with a constant $14 \%$ coefficient of variation and a pooled $t$ statistic of 1 to limit the false peak detection rate to approximately 10\% (Veldhuis \& Johnson 1986). The pulse parameters measured for each $24 \mathrm{~h}$ profile were pulse frequency, pulse height, pulse amplitude, nadir and peak width.

Circadian rhythm detection Circadian rhythms in plasma cortisol concentrations were detected using a single cosinor model developed for Microsoft Excel (Microsoft Corp., USA) (Bourdon et al. 1995). The amplitudes and times of peak concentrations (acrophase) were obtained using this model in which the data were represented by the best fitting cosine function using the least squares calculation.

Statistical analyses Plasma cortisol concentrations are represented as means \pm S.E.M. Statistical comparisons were performed using analysis of variance (MINITAB for Windows, Release 11.21, Minitab Inc., PA, USA). A blocking structure was used to separate the between- and within-animal variations. When significant $(P<0 \cdot 05)$ trends were present, between-month comparisons were made using Student's $t$-test.

For the ACTH and yarding cortisol responses, the baseline values were calculated as the average of the 2 samples collected before the imposition of the treatment. Peak heights were defined as the maximum cortisol concentration observed after treatment initiation. Blood sample collection using the DracPac device was by continuous withdrawal over the $10 \mathrm{~min}$ sampling period. Therefore, cortisol concentrations for each sample represented an integrated value for that sampling period allowing the area under the cortisol response curve to be calculated by summing the measured concentrations observed after imposition of the treatments $(190 \mathrm{~min}$ and $70 \mathrm{~min}$ for $\mathrm{ACTH}$ challenge and yarding stressor respectively).

\section{Results}

The percentage of samples collected successfully using the remote blood sampling device was $90 \%$ for the $24 \mathrm{~h}$ sampling (days 2-3) and 77\% during the challenges. Loss of samples was mainly due to severing of blood collection lines between the catheter and the blood sampler. 

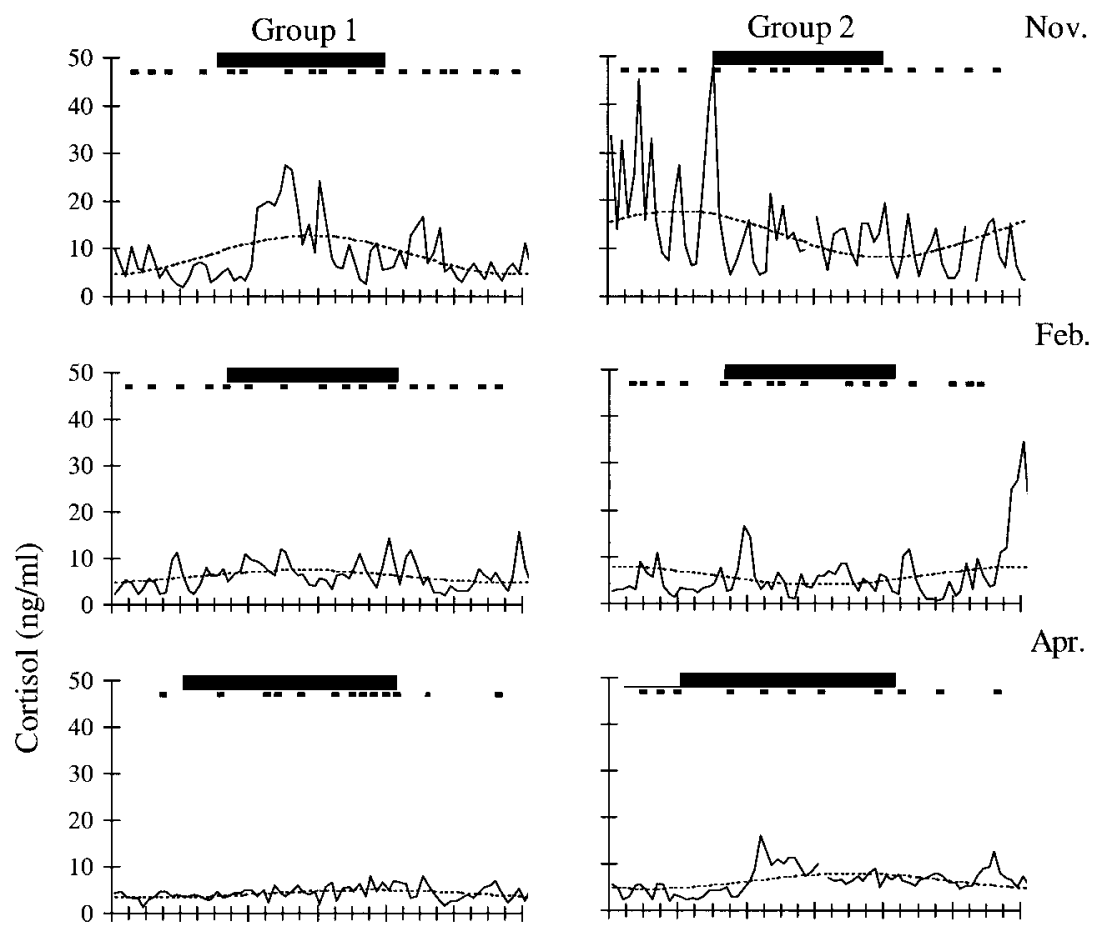

Feb.
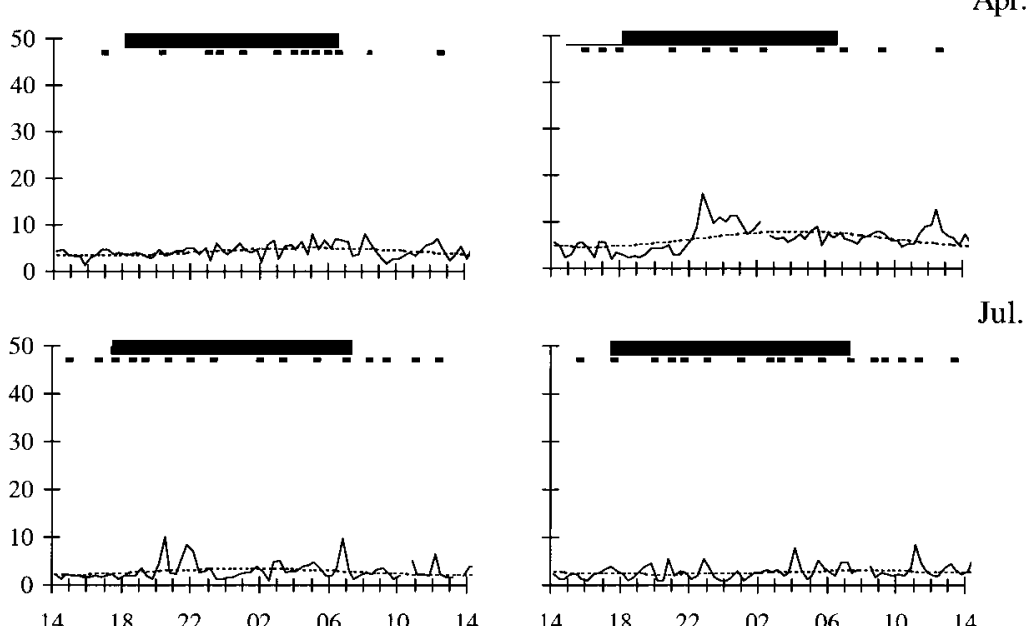

Jul.

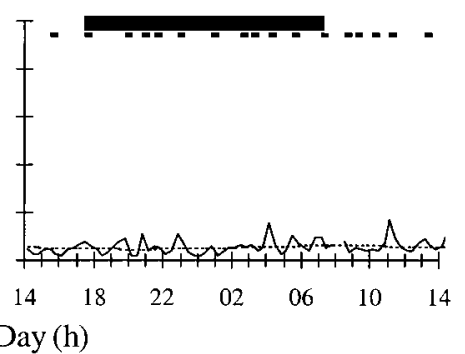

Figure 2 Seasonal effects on 24 h profiles of plasma cortisol collected from a representative stag from each group (1 and 2) at four different times of the year November (Nov.), February (Feb.), April (Apr.) and July (Jul.). The occurrences of cortisol pulses as detected by cluster analysis are shown as points at the top of each graph. Significant circadian rhythms are represented by the best fitting sine curve (dashed line) for each data series derived from COSINOR analysis. The black bars at the top of each graph represent the period of darkness for each month.

Animal live weights increased significantly $(P<0 \cdot 001)$ from a mean of $116 \cdot 7 \pm 2 \cdot 3 \mathrm{~kg}$ in November 1995 to a peak of $135 \cdot 3 \pm 2 \cdot 3 \mathrm{~kg}$ in February 1996. Mean live weights tended to decline in April $(131 \cdot 8 \pm 2 \cdot 3 \mathrm{~kg})$ and again in July $(127 \cdot 2 \pm 2 \cdot 3 \mathrm{~kg})$, although these differences were not statistically significant $(P>0 \cdot 05)$.

\section{Twenty-four hour cortisol profiles}

Representative profiles of cortisol concentration over $24 \mathrm{~h}$ for 2 stags (one from each replicate group) for each month are presented in Fig. 2. Cortisol profiles were characterised by a pulsatile secretory pattern and described by the following parameters: pulse frequency, mean pulse height, mean nadir, mean pulse amplitude, and mean pulse width. The mean values for the six experimental animals for each of the four months are shown in Table 1. The frequency of cortisol pulses did not differ significantly between November, February and July, although pulse frequencies obtained in April were significantly lower $(P<0 \cdot 01)$ than those in November and July. On average, cortisol pulses occurred once every $72 \mathrm{~min}$, a frequency of 0.8 peaks $/ \mathrm{h}$. The height, nadir and amplitude of the cortisol pulses were significantly higher $(P<0 \cdot 001)$ in November than at other times of the year. Cortisol pulse duration was significantly longer $(P<0 \cdot 05)$ in April 
Table 1 Seasonal effects on mean plasma cortisol concentrations $(\mathrm{ng} / \mathrm{ml})$ and cortisol pulse parameters (means \pm S.E.M.) derived from cluster analysis of $24 \mathrm{~h}$ cortisol profiles collected from six red deer stags at four different times of the year

\begin{tabular}{|c|c|c|c|c|}
\hline & November & February & April & July \\
\hline Cortisol (24 h mean) & $12 \cdot 5 \pm 1 \cdot 0^{\mathrm{a}}$ & $6 \cdot 3 \pm 1 \cdot 0^{b}$ & $4 \cdot 0 \pm 1 \cdot 0^{b}$ & $4 \cdot 2 \pm 1 \cdot 0^{b}$ \\
\hline \multicolumn{5}{|l|}{ Pulse } \\
\hline Frequency (pulses/h) & $0.89 \pm 0.03^{a}$ & $0 \cdot 82 \pm 0.03^{a b}$ & $0.72 \pm 0.03^{b}$ & $0 \cdot 90 \pm 0.03^{a}$ \\
\hline Height $(\mathrm{ng} / \mathrm{ml})$ & $17 \cdot 1 \pm 1 \cdot 3^{\mathrm{a}}$ & $9 \cdot 0 \pm 1 \cdot 3^{b}$ & $5 \cdot 7 \pm 1 \cdot 3^{\mathrm{b}}$ & $6 \cdot 5 \pm 1 \cdot 3^{b}$ \\
\hline Nadir $(\mathrm{ng} / \mathrm{ml})$ & $7 \cdot 5 \pm 0 \cdot 6^{a}$ & $3 \cdot 4 \pm 0 \cdot 6^{b}$ & $2 \cdot 8 \pm 0 \cdot 6^{\mathrm{b}}$ & $2 \cdot 3 \pm 0 \cdot 6^{b}$ \\
\hline Amplitude (ng/ml) & $9 \cdot 7 \pm 0 \cdot 8^{a}$ & $5 \cdot 3 \pm 0 \cdot 8^{b}$ & $2 \cdot 9 \pm 0 \cdot 8^{b}$ & $4 \cdot 1 \pm 0 \cdot 8^{b}$ \\
\hline Width (min) & $61 \cdot 1 \pm 2 \cdot 6^{\mathrm{a}}$ & $62 \cdot 6 \pm 2 \cdot 6^{\mathrm{ab}}$ & $69 \cdot 5 \pm 2 \cdot 6^{b}$ & $57 \cdot 2 \pm 2 \cdot 6^{\mathrm{a}}$ \\
\hline
\end{tabular}

Values with different superscripts are significantly different $(P \leq 0 \cdot 05)$ between months.

compared with November and July. Pulses in February were of intermediate duration and not significantly different.

Individual mean $24 \mathrm{~h}$ plasma cortisol concentrations ranged from 1.9 to $22.5 \mathrm{ng} / \mathrm{ml}$ over seasons and were significantly higher $(P<0 \cdot 001)$ in November than at other times of the year.

Significant $(P<0 \cdot 05)$ circadian rhythms were found in 9 of the 20 cortisol profiles suitable for analysis (Table 2). Another two profiles in February approached significance $(P=0 \cdot 051$ and $P=0 \cdot 061)$ and were included in the overall analysis. Parameters of the fitted sine curves are also given in Table 2. The amplitude of the circadian rhythm when present tended to be higher in November than in February, April and July, although this difference was not significant $(P=0 \cdot 146$, overall mean $3 \cdot 8 \pm 1 \cdot 4 \mathrm{ng} / \mathrm{ml})$. The acrophase (highest point) of the circadian rhythm in cortisol secretion occurred at significantly different $(P<0 \cdot 05)$ times of the day in April and February, while the times of the acrophase in November and July were not significantly different $(P>0 \cdot 05)$ from either April or February.

\section{ACTH challenge}

The mean cortisol concentrations following ACTH challenge for each of the four months are presented in
Fig. 3. The preinfusion cortisol concentrations were not significantly different $(P>0 \cdot 05)$ between months (mean $4 \cdot 6 \pm 0 \cdot 4 \mathrm{ng} / \mathrm{ml})$. Peak cortisol concentrations following ACTH infusion were significantly higher $(P<0.05)$ in November $(55.8 \pm 2.7 \mathrm{ng} / \mathrm{ml})$ and lower $(P<0.001)$ in April $(33.7 \pm 1.8 \mathrm{ng} / \mathrm{ml})$ than those in February and July $(48 \cdot 7 \pm 2 \cdot 0 \mathrm{ng} / \mathrm{ml}$ and $45 \cdot 4 \pm 2 \cdot 0 \mathrm{ng} / \mathrm{ml}$ respectively).

The area under the cortisol response curve was significantly smaller in April $(266.6 \pm 15 \cdot 3 \mathrm{ng} / \mathrm{ml} / 190 \mathrm{~min})$ $(P<0 \cdot 05)$ than at other times of the year (February, $366 \cdot 1 \pm 15 \cdot 3 \mathrm{ng} / \mathrm{ml} / 190 \mathrm{~min}$; July, $340 \cdot 7 \pm 15 \cdot 3 \mathrm{ng} / \mathrm{ml} /$ $190 \mathrm{~min}$ and November, $387 \cdot 8 \pm 21 \cdot 2 \mathrm{ng} / \mathrm{ml} / 190 \mathrm{~min}$ ).

\section{Yarding stressor}

The mean cortisol concentrations in response to the yarding stressor for each of the four months are presented in Fig. 4. The concentration of cortisol in baseline samples taken before the yarding stressor did not differ significantly between months (mean $4.2 \pm 0.5 \mathrm{ng} / \mathrm{ml}$ ). There were no significant seasonal differences in the peak concentrations of cortisol following yarding (November 23.1 $\pm 5 \cdot 6 \mathrm{ng} /$ $\mathrm{ml}$; February $20.7 \pm 4.9 \mathrm{ng} / \mathrm{ml}$; April $10.9 \pm 5.6 \mathrm{ng} / \mathrm{ml}$ and July $9 \cdot 7 \pm 4.6 \mathrm{ng} / \mathrm{ml}$ ), or in the area under the cortisol response curve (November $81.5 \pm 32.2 \mathrm{ng} / \mathrm{ml} / 70 \mathrm{~min}$; February $101.6 \pm 27 \cdot 9 \mathrm{ng} / \mathrm{ml} / 70 \mathrm{~min} ;$ April $47 \cdot 9 \pm$ $32 \cdot 2 \mathrm{ng} / \mathrm{ml} / 70 \mathrm{~min}$ and July $40 \cdot 1 \pm 26 \cdot 6 \mathrm{ng} / \mathrm{ml} / 70 \mathrm{~min}$ ).

Table 2 Circadian effects on plasma cortisol concentrations derived from COSINOR analysis of $24 \mathrm{~h}$ cortisol profiles at four different times of the year (means \pm S.E.M.)

\begin{tabular}{|c|c|c|c|c|}
\hline & November & February & April & July \\
\hline No. of animals* & $4 / 6$ & $2^{\dagger} / 4$ & $3 / 5$ & $2 / 5$ \\
\hline Amplitude $(\mathrm{ng} / \mathrm{ml})^{+}$ & $8 \cdot 4 \pm 2 \cdot 5^{a}$ & $1 \cdot 5 \pm 2 \cdot 5^{\mathrm{a}}$ & $1 \cdot 1 \pm 2 \cdot 5^{\mathrm{a}}$ & $2 \cdot 1 \pm 2 \cdot 5^{\mathrm{a}}$ \\
\hline Acrophase (h:min) $)^{\S}$ & $00: 07 \pm 2: 29^{a b}$ & $17: 44 \pm 2: 29^{a}$ & $06: 42 \pm 2: 29^{b}$ & $01: 36 \pm 2: 29^{\mathrm{ab}}$ \\
\hline
\end{tabular}

*No. of animals indicates stags exhibiting a significant $(P<0 \cdot 05)$ circadian rhythm in plasma cortisol concentrations out of those stags with a complete $24 \mathrm{~h}$ profile (i.e. $\geq 72$ samples). ${ }^{+}$Amplitude is the mean amplitude of the fitted sine curve expressed as $\mathrm{ng} / \mathrm{ml}$. ${ }^{\S}$ Acrophase is the mean time of day that the sine wave is maximal, expressed in hours and minutes. ${ }^{\dagger}$ In February the two animals had rhythms that approached significance $(P=0.051$ and $P=0.061$ respectively). Values with different superscripts are significantly different $(P \leqslant 0 \cdot 05)$ between months. 


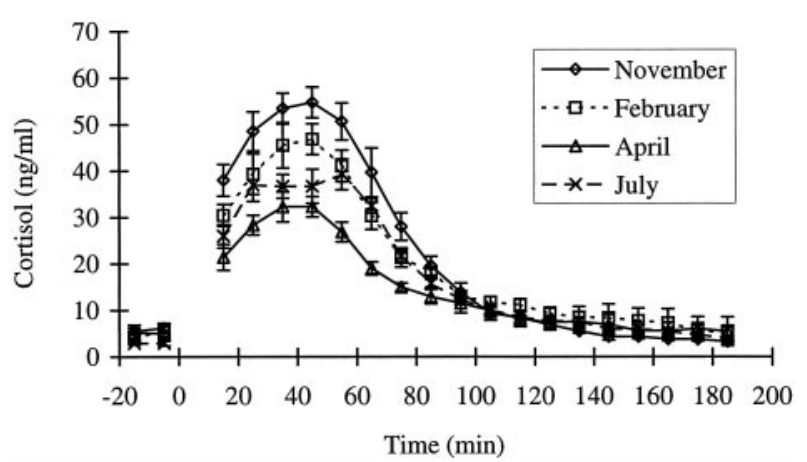

Figure 3 Seasonal effects on adrenocortical responses to ACTH $_{1-24}$ challenge $\left(0 \cdot 04 \mathrm{IU} \mathrm{kg}^{-1}\right)$ administered at time 0 , to free-ranging red deer stags at pasture in November $(n=4)$, February $(n=5)$, April $(n=5)$ and July $(n=5)$. Values are shown as the monthly means \pm S.E.M.

\section{Discussion}

This study has shown that basal cortisol secretion in red deer stags is characterised by an episodic pattern of release from the adrenal gland, a feature common in other species (humans (Krieger et al. 1971); primates (Sarnyai et al. 1995); sheep (Fulkerson \& Tang 1979)). Significant pulses in cortisol concentration occurred on average every $72 \mathrm{~min}$, a frequency $(0.8$ peaks $/ \mathrm{h})$ similar to that reported for Eld's deer (0.6 peaks/h (Monfort et al. 1993)), and other ruminant species including cattle $(0.5$ peaks $/ \mathrm{h}$ (Ladewig \& Schmidt 1989, Lefcourt et al. 1993)), sheep (0.8-1.2 peaks/h (Fulkerson \& Tang 1979)) and non ruminant species such as the horse $(0.6$ peaks/h (Irvine \& Alexander 1994)). This pulsatile release of cortisol during periods of normal undisturbed activity may function to prevent down regulation of the adrenal axis, thereby maintaining the ability of the axis to respond maximally to stressors.

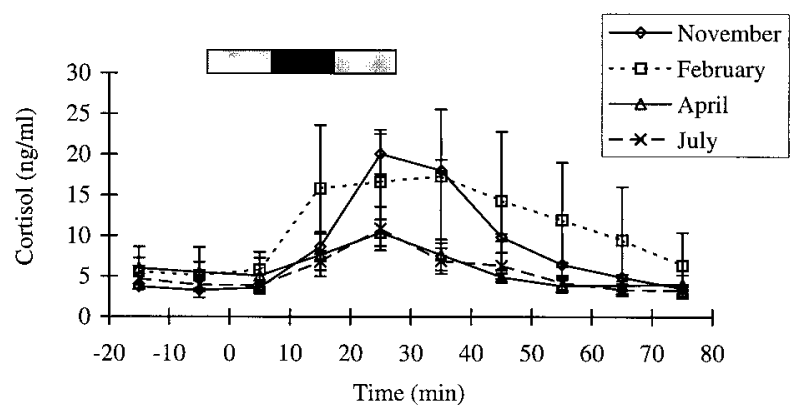

Figure 4 Seasonal effects on the adrenocortical response of free ranging red deer stags to a yarding stressor and subsequent recovery at pasture in November $(n=4)$, February $(n=5)$, April $(n=4)$ and July $(n=5)$. Grey bars indicate time spent moving to and from yards, the black bar indicates time spent in yards. Values are shown as the monthly means \pm S.E.M.
Individual mean $24 \mathrm{~h}$ concentrations of plasma cortisol found in the present study $(1.9$ to $22.5 \mathrm{ng} / \mathrm{ml})$ are similar to basal cortisol concentrations reported for hand-reared Eld's deer (5·4-14.5 ng/ml (Monfort et al. 1993)) and in previous studies using the DracPac remote sampling device on undisturbed red deer stags $(5 \cdot 4-22 \mathrm{ng} / \mathrm{ml}$ (Ingram et al. 1994, 1997, Matthews et al. 1994, Carragher et al. 1997, Waas et al. 1997)) as well as in stag blood sampled immediately after being shot dead while undisturbed at pasture $(5.7 \pm 3.7 \mathrm{ng} / \mathrm{ml}$ (Smith \& Dobson 1990)). These basal concentrations are generally lower than those reported for red deer in studies where animals have been physically or chemically restrained prior to blood sampling (6-27 ng/ml (Jopson et al. 1990); 18$27 \mathrm{ng} / \mathrm{ml}$ (Goddard et al. 1994); 17-55 ng/ml (Bubenik \& Bartos 1993)). This indicates that in previous studies, restraint artefacts have been a potential confounding factor in the assessment of adrenal activity and function in red deer.

The presence of a circadian rhythm in plasma glucocorticoid concentrations is well established in humans (Weitzman et al. 1971) and rodents (Keller-Wood \& Dallman 1984) and involves an anticipatory rise in cortisol prior to the activity phase, which is typically entrained by circadian rhythms in feeding (Saito et al. 1989) and resting (Born et al. 1997). In ruminants, contradictory reports exist about the presence of circadian rhythms in basal plasma cortisol concentrations. For example, in cattle several authors have reported a circadian rhythm in cortisol concentrations (Hays et al. 1975, Fulkerson et al. 1980, Thun et al. 1981, Lefcourt et al. 1993) whereas Hudson et al. (1975) failed to detect any circadian rhythm. Such rhythms in cortisol concentrations have not been identified in white-tailed deer (Bubenik et al. 1983), rusa deer (van Mourik \& Stelmasiak 1984) or Eld's deer (Monfort et al. 1993), although the existence of a circadian rhythm in the latter study could not be ruled out as the animals were blood sampled for only $10 \mathrm{~h}$ per day. The deer in these studies were all subjected to either handling or indoor housing, factors known to attenuate circadian rhythms in horses (Irvine \& Alexander 1994). In the present study, a significant circadian rhythm in plasma cortisol concentrations was found in half of the $24 \mathrm{~h}$ profiles suitable for analysis. Amplitudes were generally small, the exception being November, when a sustained period of agonistic behaviour in one group (data not shown) may have contributed to increased amplitudes.

Where reported, circadian rhythms are typically of low amplitude in ruminants (e.g. cattle, 1-1.4 ng/ml (Thun et al. 1981, Lefcourt et al. 1993)). At pasture, ruminants such as sheep, cattle and deer graze and rest in bouts throughout the day and night (Gates \& Hudson 1983, Kilgour \& Dalton 1984). Thus, they may not have the same cues available for entrainment of a circadian rhythm compared with non-ruminants or ruminants maintained indoors on fixed feeding schedules. While there is some 
evidence from our study for circadian variability in cortisol concentrations in red deer at pasture, this rhythm is of low amplitude and potentially easily disrupted by stress associated with handling and blood sampling or social and environmental factors (Irvine \& Alexander 1994). Further studies would be required to determine conclusively if circadian rhythms were a fundamental feature of HPA axis activity in red deer stags.

Seasonal rhythms in activity, behaviour, metabolism and secretion of hormones are well documented in cervid species (Lincoln et al. 1970, Loudon \& Brinklow 1992, Suttie et al. 1992, Asher et al. 1996). In the present study significant seasonal rhythms were observed in the dynamics of $24 \mathrm{~h}$ cortisol secretion from the adrenal cortex of red deer stags. The frequency of cortisol pulses was significantly lower during the rut in red deer stags which contrasts with the lack of a seasonal pattern found in Eld's deer (Monfort et al. 1993) and may reflect fundamental differences between the two species of deer (temperate vs tropical habitat, autumn vs spring breeding). The role androgens might play in modulating the pulsatile nature of HPA axis activity in red deer has yet to be investigated; however, androgens have been shown to suppress corticotrophin releasing hormone levels within the paraventricular nucleus (Bingaman et al. 1994) suggesting a central site of action (Handa et al. 1994).

November (southern hemisphere) is a unique time of year for red deer stags. It represents a degree of sexual quiescence uncommon in many other domestic ruminants. Secretion of luteinizing hormone (LH) from the pituitary and testosterone from the testes is negligible (i.e. pulse frequency of $\mathrm{LH}$ and testosterone is less than one pulse per $24 \mathrm{~h}$ and basal concentrations of LH and testosterone are below detectable concentrations (Suttie et al. 1992)). With no significant testicular activity, stags behave similarly to castrated animals (Lincoln et al. 1970). Major changes also occur in appetite, feed utilisation and fat accretion (Asher et al. 1994). The increase in cortisol pulse height, pulse nadir and pulse amplitude in November indicates that there is a shift in the regulation of the HPA axis during spring. Changes in height and amplitude reflect to some extent the increased responsiveness of the adrenal gland to ACTH seen at this time of year (Suttie et al. 1995, Cassidy 1996). However, the threefold increase in cortisol pulse parameter values compared with that seen during the rut would suggest that the adrenal gland changes are also accompanied by changes in endogenous ACTH secretion. Due to its rapid degradation in blood, ACTH could not be measured in remotely collected samples. However, male Soay sheep which display similar seasonal rhythms in basal cortisol concentrations and adrenal responsiveness to ACTH also show a marked seasonal variation in endogenous ACTH secretion with the peak concentrations occurring during the seasonal peak in cortisol concentrations (Ssewannyana et al. 1990). The increase in nadir also implies an up regulation of the central drive to the
HPA axis in conjunction with a down regulation of the glucocorticoid negative feedback system controlling the axis.

The increase in cortisol pulse parameters in November translated into greater mean $24 \mathrm{~h}$ cortisol concentrations which were significantly higher than those at other times of the year. Seasonal changes in cortisol secretion have been reported in males of some other seasonally breeding deer species. Cortisol concentrations have been reported to decline during the rut in white-tailed deer (Bubenik et al. 1983), reindeer (Nilssen et al. 1985) and axis deer (Chapple et al. 1991), while other studies have reported increased concentrations during the rut for red deer (Feher et al. 1994), or no change in reindeer (Ringberg 1979) and Eld's deer (Monfort et al. 1993). The metabolic and reproductive implications of a seasonal rhythm in basal cortisol concentrations in red deer stags are discussed below.

Alternatively, the decline in basal cortisol concentrations over the course of the experiment may result from a process of habituation to the remote blood sampling procedure. However, subsequent experiments (J R Ingram, unpublished data) conducted in November and April using red deer stags naive to the blood sampling procedure on both occasions, have revealed similar seasonal differences in cortisol concentrations to those found in the present study.

Cortisol concentrations and the temporal pattern of release from the adrenal gland in response to ACTH challenge were similar to those previously reported for red deer stags using the DracPac technique (Ingram et al. 1997). The maximum cortisol concentrations were within the range reported for red deer following ACTH challenge (males: 26 to $100 \mathrm{ng} / \mathrm{ml}$ (Bubenik \& Bartos 1993, Ingram et al. 1997); females: 40 to $90 \mathrm{ng} / \mathrm{ml}$ (Jopson et al. 1990, Goddard et al. 1994)) and following routine handling procedures in our facility (males: 25 to $70 \mathrm{ng} / \mathrm{ml}$ (Matthews \& Cook 1991, Ingram et al. 1994, 1997, Matthews et al. 1994, Carragher et al. 1997)). In the present study, red deer stags displayed significant seasonal variation in response to ACTH challenge. Maximal responses were higher in November (spring) and declined to a minimum in April (mid rut, autumn). Recent studies of adrenal responsiveness in red deer stags (Suttie et al. 1995, Cassidy 1996) have shown a similar seasonal rhythm with greater plasma cortisol responses to ACTH challenge during spring/summer compared with the breeding season and winter months.

Significant elevations in plasma cortisol concentrations were seen in response to a standardised acute stress (yarding) at all times of the year. The amplitude of the cortisol response to yarding in November and February was twice that seen in April and July, although this seasonal variation was not statistically significant due to the large variability seen in individual responses. Peak cortisol concentrations in November and February, however, 
were similar to concentrations reported in an earlier study on stags, carried out in December $(23 \mathrm{ng} / \mathrm{ml}$ (Carragher et al. 1997)), using the DracPac blood sampling technique and a similar yarding challenge. The generally lower cortisol responses in April and July would suggest either a reduced capacity of the HPA axis to respond to stress as supported by the ACTH challenge data, or a reduction in the perceived stressfulness of the yarding procedure possibly mediated via either habituation to the challenge or the attenuating effects of testosterone on fearfulness (Boissy \& Bouissou 1994).

Compared with other routine handling procedures that have been evaluated using the DracPac technique, such as restraint (Ingram et al. 1994, Carragher et al. 1997), removal of growing antler (Matthews et al. 1994) and transport (Waas et al. 1997), the increase in cortisol secretion following yarding was of lessor amplitude and of short duration indicating that the procedure was potentially less stressful.

It is evident from this study that red deer stags have a strong seasonal rhythm in HPA axis activity and responsiveness. The mechanism by which this change occurs has yet to be determined in red deer, although these changes closely follow seasonal rhythms in testicular function (Suttie et al. 1992) and growth rates (Kay 1979). Testosterone concentrations which peak in stags during the rut (Suttie et al. 1992), can inhibit cortisol secretion directly by influencing steroidogenic pathways involved in the synthesis of cortisol in the adrenal cortex (Hornsby 1982, Miller 1988). It is possible that the hypertrophy and hyperplasia of the adrenal cortex seen in rutting wild red deer stags (Kapp 1989) and white-tailed deer stags (Hoffman \& Robinson 1966) is in response to the reduced ability of the adrenal to produce cortisol at this time.

In addition, androgens can influence HPA axis activity by competing with cortisol for binding sites on carrier proteins such as corticosteroid binding globulin (CBG) (Bradley \& Stoddart 1992) and plasma albumin (Ward et al. 1992). Androgens can also suppress hepatic synthesis of CBG (Gala \& Westphal 1965) effectively increasing unbound concentrations of cortisol. This, in turn, would increase negative feedback to the HPA axis, reducing HPA axis activity and trophic drive to the adrenal cortex. A further mechanism by which androgens can influence HPA axis activity is by binding to androgen receptors in regions of the central nervous system such as the hippocampus known to modulate the HPA axis (Handa et al. 1994).

The seasonal rhythm in plasma cortisol concentrations found in the present study also correlates with the seasonal cycle in growth in the red deer stag, with higher concentrations of cortisol during the period of weight gain in November and reduced concentrations during periods of weight loss during the rut. Interestingly, humans suffering from Cushing's syndrome (chronic hypercortisolaemia) show clinical signs of obesity whereas adrenocortical deficiency (chronic hypocortisolaemia) in humans is characterised by weight loss (Hauner et al. 1987).

The dramatic increase in weight during the spring and early summer and the higher levels of plasma cortisol coincide with elevated insulin concentrations and the development of insulin resistance in red deer stags (McMahon et al. 1997). It is well established that glucocorticoids stimulate feeding behaviour and insulin secretion (Dallman et al. 1995), and that cortisol excess can cause insulin resistance and obesity in humans (Brandes 1977). Cortisol promotes differentiation of adipocyte precursors into adipocytes and stimulates lipogenesis in the presence of insulin (Grégoire et al. 1991), and may have a role to play in the increased appetite, feed utilisation and fat accretion at this time of year in stags.

The period of the rut, with its increased aggression (Suttie 1985) and pronounced weight loss (Kay 1979), could be considered a period of increased social and nutritional stress. Chronic social stress has been reported to reduce plasma cortisol concentrations in female red deer (Goddard et al. 1994), yearlings (Hanlon et al. 1995) and stags (J R Ingram, unpublished data), while prolonged periods of weight loss in humans (over 26 weeks) resulted in a significant decrease in concentrations of cortisol and cortisol-binding globulin but no change in the concentration of free cortisol (Yanovski et al. 1997). In addition, nutritional stress is often associated with a metabolic disorder termed fatty liver syndrome. Red deer stags during the rut in the wild have a high incidence $(80 \%)$ of fatty liver syndrome (Kapp et al. 1989) which may impair liver function reducing the synthesis of CBG (Veldman \& Meinders 1996) and can directly inhibit steroidogenesis by limiting the availability of cholesteryl esters used in the synthesis of steroid hormones (Morrow et al. 1979, Nakagawa et al. 1997).

Glucocorticoid excess stimulates bone resorption and inhibits bone formation resulting in accelerated bone loss (Kleerekoper et al. 1997). Deer undergo skeletal bone loss during antler growth in spring (Hillman et al. 1973). The elevated concentrations of cortisol during the period of new antler growth in the present study and during antler mineralisation in late summer (Suttie et al. 1995) suggest a role for this steroid in red deer new antler growth.

The inhibitory influence of the HPA axis upon the reproductive axis (reviewed in Rivest \& Rivier 1995) and immune function (reviewed in Munck et al. 1984) is well established in many animals. Therefore, it may be advantageous for stags during the breeding season, when inter-male competition for females is intense, to have reduced activity and responsiveness of the HPA axis as a strategy to maintain reproductive and immune competence in the face of increased physical and psychological stress.

In summary, the current data demonstrate that there is episodic activity of the HPA axis. There are also strong 
seasonal effects on HPA axis activity and responsiveness to ACTH challenge in red deer stags. November, a period of reproductive quiescence, new antler growth and rapid weight gain, is associated with higher mean plasma cortisol concentrations and a greater responsiveness to ACTH. In contrast, the breeding season is associated with lower adrenal activity and responsiveness. The mechanisms involved have yet to be elucidated for red deer; however the inhibitory actions of androgens, variations in metabolic demand and exogenous factors such as chronic social/ nutritional stress may be important factors. This study also highlights the advantages of remote blood sampling technology in obtaining undisturbed measurements of HPA axis activity and functioning without the confounding effects of repeated handling and restraint stress, information which is essential before reliable physiological measures of stress can be determined.

\section{Acknowledgements}

The authors wish to thank Dudley Bell, Kaye Bremner, John Carragher, Jenny Jago, Andrew Phipps, Jacqui Todd, Joe Waas and Jacqui Walker for their assistance in the sampling of animals, Neil Cox for advice with the statistical analyses, Drs Geoff Asher, Catherine Morrow and Andrew Fisher for comments on the manuscript and Paul Gaastra, James Pinfold, Rod McDonald and Peter Schare for design and construction of the DracPacs. This study was funded by the Foundation for Research Science and Technology.

\section{References}

Asher GW, Fisher MW, McLeod BJ \& Berg DK 1994 Reproductive physiology of cervids: a review. Proceedings of a Deer Course for Veterinarians No 11, New Zealand Veterinary Association, Deer Branch 11 257-277.

Asher GW, Berg DK, Beaumont S, Morrow CJ, O’Neill KT \& Fisher MW 1996 Comparison of seasonal changes in reproductive parameters of adult male European fallow deer (Dama dama dama) and hybrid Mesopotamian $\times$ European fallow deer $(D . d$. mesopotamica $\times$ D. d. dama). Animal Reproduction Science 45 201-215.

Barnett JL \& Hemsworth PH 1990 The validity of physiological and behavioural measures of animal welfare. Applied Animal Behaviour Science 25 177-187.

Bass JJ, Fairclough RT, Peterson AJ, Nottingham R \& Payne E 1982 Effect of castration and testosterone therapy on adrenocortical response to synthetic corticotrophin (Synacthen) in bulls. Proceedings of the New Zealand Society of Endocrinology 252 (Abstract).

Bingaman EW, Magnuson DJ, Gray TS \& Handa RJ 1994 Androgen inhibits the increase in hypothalamic corticotropin-releasing hormone $(\mathrm{CRH})$ and $\mathrm{CRH}$-immunoreactivity following gonadectomy. Neuroendocrinology $59228-234$

Boissy A \& Bouissou MF 1994 Effects of androgen treatment on behavioural and physiological responses of heifers to fear-eliciting situations. Hormones and Behavior 28 66-83.

Born J, Steinbach D, Dodt C \& Fehm H 1997 Blocking of central nervous mineralocorticoid receptors counteracts inhibition of pituitary-adrenal activity in human sleep. Journal of Clinical Endocrinology and Metabolism 82 1106-1110.
Boswell T, Woods SC \& Kenagy GJ 1994 Seasonal changes in body mass, insulin, and glucocorticoids of free-living golden-mantled ground squirrels. General and Comparative Endocrinology 96 339-346.

Bourdon L, Buguet A, Cacherat M \& Radomski MW 1995 Use of a spreadsheet program for circadian analysis of biological/physiological data. Aviation, Space and Environmental Medicine 66 787-791.

Bradley AJ \& Stoddart DM 1992 Seasonal changes in plasma androgens, glucocorticoids and glucocorticoid-binding proteins in the marsupial sugar glider Petaurus breviceps. Journal of Endocrinology 132 21-31.

Brandes JS 1977 Insulin induced overeating in the rat. Physiology and Behavior 18 1095-1102.

Bubenik GA \& Brown RD 1989 Seasonal levels of cortisol, triiodothyronine and thyroxine in male axis deer. Comparative Biochemistry and Physiology 92A 499-503.

Bubenik GA \& Bartos L 1993 Cortisol levels in red deer (Cervus elaphus) and fallow deer (Dama dama) after an acute ACTH administration. Canadian Journal of Zoology 71 2258-2261.

Bubenik GA, Bubenik AB, Schams D \& Leatherland JF 1983 Circadian and circannual rhythms of LH, FSH, testosterone (T), prolactin, cortisol, T3 and T4 in plasma of mature, white-tailed deer. Comparative Biochemistry and Physiology 76A 37-45.

Carragher JF, Ingram JR \& Matthews LR 1997 Effects of yarding and handling procedures on stress responses of free-ranging red deer (Cervus elaphus). Applied Animal Behaviour Science 51 143-158.

Cassidy AM 1996 The relationship between behaviour and adrenocortical response to administration of adrenocorticotropic hormone (ACTH) in farmed red deer (Cervus elaphus). MSc thesis, University of Otago, Dunedin, New Zealand.

Chapple RS, English AW, Mulley RC \& Lepherd EE 1991 Haematology and serum biochemistry of captive unsedated chital deer (Axis (Cervus) axis) in Australia. Journal of Wildlife Diseases 27 396-406.

Dallman MF, Akana SF, Strack AM, Hansen ES \& Sebastian RJ 1995 The neural network that regulates energy balance is responsive to glucocorticoids and insulin and also regulates HPA axis responsivity at a site proximal to CRF neurons. Annals of the New York Academy of Sciences 771 730-742.

Feher T, Zomborszky Z \& Sandor E 1994 Dehydroepiandrosterone, dehydroepiandrosterone sulphate, and their relation to cortisol in red deer (Cervus elaphus). Comparative Biochemistry and Physiology 109C 247-252.

Fraser AF \& Broom DM 1990 Farm Animal Behaviour and Welfare. London: Baillière Tindall.

Fulkerson WJ \& Tang BY 1979 Ultradian and circadian rhythms in the plasma concentration of cortisol in sheep. Journal of Endocrinology 81 135-141.

Fulkerson WJ, Sawyer GJ \& Gow CB 1980 Investigations of ultradian and circadian rhythms in the concentration of cortisol and prolactin in the plasma of dairy cattle. Australian Journal of Biological Sciences 33 557-561.

Gala RR \& Westphal U 1965 Corticosteroid-binding globulin in the rat: studies on the sex difference. Endocrinology 77 841-851.

Gates CC \& Hudson RJ 1983 Foraging behaviour of wapiti in a boreal forest enclosure. Naturaliste Canadien 110 197-206.

Goddard PJ, Rhind SM, Hamilton WJ, MacDonald AJ, Fawcett AR, Soanes C \& McMillen SR 1994 The adrenocorticotrophic hormone stimulation test: its potential use and limitations in red deer (Cervus elaphus). Canadian Journal of Zoology 72 1826-1830.

Grégoire F, Genart C, Hauser N \& Remacle C 1991 Glucocorticoids induce a drastic inhibition of proliferation and stimulate differentiation of adult rat fat cell precursors. Experimental Cell Research 196 270-278.

Handa RJ, Burgess LH, Kerr JE \& O’Keefe JA 1994 Gonadal steroid hormone receptors and sex differences in the hypothalamopituitary-adrenal axis. Hormones and Behavior 28 464-476.

Hanlon AJ, Rhind SM, Reid HW, Burrells C \& Lawrence AB 1995 Effects of repeated changes in group composition on immune 
response behaviour, adrenal activity and lightweight gain on farmed red deer yearlings. Applied Animal Behaviour Science 44 57-64.

Hauner H, Schmid P \& Pfeiffer EF 1987 Glucocorticoids and insulin promote the differentiation of human adipocyte precursor cells into fat cells. Journal of Clinical Endocrinology and Metabolism 64 832-835.

Hays FL, Armbruster H, Vetter W \& Bianca W 1975 Plasma cortisol in cattle: Circadian rhythm and exposure to a simulated high altitude of $5000 \mathrm{~m}$. International Journal of Biometeorology 19 $127-135$.

Hillman JR, Davis RW \& Abdelbaki YZ 1973 Cyclic bone remodeling in deer. Calcified Tissue Research 12 323-330.

Hoffman RA \& Robinson PF 1966 Changes in some endocrine glands of white-tailed deer as affected by season, sex and age. Journal of Mammalogy 47 266-280.

Hornsby PJ 1982 Regulation of 21-hydroxylase activity by steroids in cultured bovine adrenocortical cells: possible significance for adrenocortical androgen synthesis. Endocrinology 111 1092-1101.

Hudson S, Mullord M, Whittlestone WG \& Payne E 1975 Diurnal variations in blood cortisol in the dairy cow. Journal of Dairy Science 58 30-33.

Ingram JR, Matthews LR \& McDonald RM 1994 A stress free blood sampling technique for free ranging animals. Proceedings of the New Zealand Society of Animal Production 54 39-42.

Ingram JR, Matthews LR, Carragher JF \& Schaare PR 1997 Plasma cortisol responses to remote adrenocorticotropic hormone (ACTH) infusion in free-ranging red deer (Cervus elaphus). Domestic Animal Endocrinology 14 63-71.

Irvine CHG \& Alexander SL 1994 Factors affecting the circadian rhythm in plasma cortisol concentrations in the horse. Domestic Animal Endocrinology 11 227-238.

Jopson NB, Fisher MW \& Suttie JM 1990 Plasma progesterone concentrations in cycling and in ovariectomized red deer hinds: the effect of progesterone supplementation and adrenal stimulation. Animal Reproduction Science 23 61-73.

Kapp P 1989 New observations on the pathomorphogenesis of the fatty liver syndrome in ruminants. Magyar Allatorvosok Lapja $\mathbf{4 4}$ $157-168$.

Kapp P, Gaes T \& Bugar J 1989 Development of a fatty liver syndrome in stags during the rutting period. Magyar Allatorvosok Lapja 44 151-155.

Kay RNB 1979 Seasonal changes of appetite in deer and sheep. Agricultural Research Council Research Review (United Kingdom) 5 $13-15$.

Keller-Wood ME \& Dallman MF 1984 Corticosteroid inhibition of ACTH secretion. Endocrine Reviews 5 1-24.

Kennaway DJ, Obst JM, Dunstan EA \& Friesen HG 1981 Ultradian and seasonal rhythms in plasma gonadotropins, prolactin, cortisol, and testosterone in pinealectomized rams. Endocrinology 108 639-646.

Kilgour R \& Dalton C 1984 Livestock Behaviour. A Practical Guide, pp 320. London: Granada Publishing Ltd.

Kleerekoper M, Schiebinger R \& Gutai JP 1997 Editorial: steroid therapy for adrenal disorders - getting the dose right. Journal of Clinical Endocrinology and Metabolism 82 3923-3925.

Krieger DT, Allen W, Rizzo F \& Krieger HP 1971 Characterization of the normal temporal pattern of plasma corticosteroid levels. Journal of Clinical Endocrinology and Metabolism 32 266-284.

Ladewig J \& Stribrny K 1988 A simplified method for the stress free continuous blood collection in large animals. Laboratory Animal Science 38 333-334.

Ladewig J \& Smidt D 1989 Behaviour, episodic secretion of cortisol, and adrenocortical reactivity in bulls subjected to tethering. Hormones and Behavior 23 244-360.

Lefcourt AM, Bitman J, Kahl S \& Wood DL 1993 Circadian and ultradian rhythms of peripheral cortisol concentrations in lactating dairy cows. Journal of Dairy Science 76 2607-2612.
Lincoln GA \& Kay RN 1979 Effects of season on the secretion of LH and testosterone in intact and castrated red deer stags (Cervus elaphus). Journal of Reproduction and Fertility 55 75-80.

Lincoln GA, Youngson RW \& Short RV 1970 The social and sexual behaviour of the red deer stag. Journal of Reproduction and Fertility (Suppl) 11 71-103.

Loudon ASI \& Brinklow BR 1992 Reproduction in deer: adaptations for life in seasonal environments. In The Biology of Deer, pp 261-278. Ed. RD Brown. New York: Springer-Verlag.

Loudon ASI, Milne JA, Curlewis JD \& McNeilly AS 1989 A comparison of the seasonal hormone changes and patterns of growth, voluntary food intake and reproduction in juvenile and adult red deer (Cervus elaphus) and Père David's deer (Elaphurus davidianus) hinds. Journal of Endocrinology 122 733-745.

Lyons DM, Price EO \& Moberg GP 1988 Social modulation of pituitary-adrenal responsiveness and individual differences in behaviour of young domestic goats. Physiology and Behavior 43 451-458.

McLeese JM, Johnsson J, Huntly FM, Clarke WC \& Weisbart M 1994 Seasonal changes in osmoregulation, cortisol, and cortisol receptor activity in the gills of parr/smolt of steelhead trout and steelhead-rainbow trout hybrids, Oncorhynchus mykiss. General and Comparative Endocrinology 93 103-113.

McMahon CD, Corson ID, Littlejohn RP, Stuart SK, Veenvliet BA \& Suttie JM 1997 Effects of season, protein and nutritional state on glucose tolerance during an annual cycle of growth in young red deer stags. Journal of Endocrinology 154 275-283.

Matthews LR \& Cook CJ 1991 Deer welfare research - Ruakura findings. Proceedings of a Deer Course for Veterinarians No 8, New Zealand Veterinary Association, Deer Branch 8 74-85.

Matthews LR, Carragher JF \& Ingram JR 1994 Post-velveting stress in free-ranging red deer. Proceedings of a Deer Course for Veterinarians No 11, New Zealand Veterinary Association, Deer Branch 11 138-146.

Miller WL 1988 Molecular biology of steroid hormone synthesis. Endocrine Reviews 9 295-318.

Monfort SL, Brown JL \& Wildt DE 1993 Episodic and seasonal rhythms of cortisol secretion in male Eld's deer (Cervus eldi thamin). Journal of Endocrinology 138 41-49.

Morrow DA, Hillman D, Dade AW \& Kitchen H 1979 Clinical investigation of a dairy herd with the fat cow syndrome. Journal of the American Veterinary Medical Association 174 161-167.

van Mourik S \& Stelmasiak T 1984 The effect of immobilizing drugs on adrenal responsiveness to $\mathrm{ACTH}$ in rusa deer. Comparative Biochemistry and Physiology 78C 467-471.

van Mourik S, Stelmasiak T \& Outch KH 1985 Changes in plasma levels of cortisol and corticosterone after acute ACTH stimulation in rusa deer (Cervus rusa timorensis). Comparative Biochemistry and Physiology 81A 545-549.

Munck A, Guyer PM \& Holbrook NY 1984 Physiological functions of glucocorticoids in stress and their relation to pharmacological actions. Endocrine Reviews 5 25-44.

Nakagawa H, Oikawa S, Oohashi T \& Katoh N 1997 Decreased serum lecithin:cholesterol acyltransferase activity in spontaneous cases of fatty liver in cows. Veterinary Research Communications 21 $1-8$.

Nilssen KJ, Bye K, Sundsfjord JA \& Blix AS 1985 Seasonal changes in T3, FT4, and cortisol in free-ranging Svalbard reindeer (Rangifer tarandus platyrhynchus). General and Comparative Endocrinology $\mathbf{5 9}$ 210-213.

Reimers TJ, McCann JP \& Cowan RG 1983 Effects of storage times and temperatures on T3, T4, LH, prolactin, insulin, cortisol and progesterone concentrations in blood samples from cows. Journal of Animal Science 57 683-691.

Ringberg T 1979 The Spitzbergen reindeer - a winter-dormant ungulate? Acta Physiologica Scandinavica 105 268-273.

Rivest S \& Rivier C 1995 The role of corticotropin-releasing factor and interleukin-1 in the regulation of neurons controlling reproductive functions. Endocrine Reviews 16 117-199. 
Saito M, Nishimura K \& Kato H 1989 Modifications of circadian cortisol rhythm by cyclic and continuous total enteral nutrition. Journal of Nutritional Science and Vitaminology 35 639-647.

Sarnyai Z, Veldhuis JD, Mello NK, Mendelson JH, Erös-Sarnyai M, Mercer G, Gelles H \& Kelly M 1995 The concordance of pulsatile ultradian release of adrenocorticotropin and cortisol in male rhesus monkeys. Journal of Clinical Endocrinology and Metabolism 80 54-59.

Schiml PA, Mendoza SP, Saltzman W, Lyons DM \& Mason WA 1996 Seasonality in squirrel monkeys (Saimiri sciureus): social facilitation by females. Physiology and Behavior 60 1105-1113.

Smith JH \& Bubenik GA 1990 Plasma concentrations of glucocorticoids in white-tailed deer: the effect of acute ACTH and dexamethasone administration. Canadian Journal of Zoology 68 2123-2129.

Smith RF \& Dobson H 1990 Effect of preslaughter experience on behaviour, plasma cortisol and muscle $\mathrm{pH}$ in farmed deer. Veterinary Record 126 155-158.

Ssewannyana E, Lincoln GA, Linton EA \& Lowry PJ 1990 Regulation of the seasonal cycle of $\beta$-endorphin and ACTH secretion into the peripheral blood of rams. Journal of Endocrinology 124 443-454.

Suttie JM 1985 Social dominance in farmed red deer stags. Applied Animal Behaviour Science 14 191-199.

Suttie JM, Fennessy PF, Corson ID, Laas FJ, Crosbie SF, Butler JH \& Gluckman PD 1989 Pulsatile growth hormone, insulin-like growth factors and antler development in red deer (Cervus elaphus scoticus) stags. Journal of Endocrinology 121 351-360.

Suttie JM, Fennessy PF, Corson ID, Veenvliet BA, Littlejohn RP \& Lapwood KR 1992 Seasonal pattern of luteinizing hormone and testosterone pulsatile secretion in young adult red deer stags (Cervus elaphus) and its association with the antler cycle. Journal of Reproduction and Fertility 95 925-933.

Suttie JM, Fennessy PF, Lapwood KR \& Corson ID 1995 Role of steroids in antler growth of red deer stags. Journal of Experimental Zoology 271 120-130.

Thun R, Eggenberger E, Zerobin K, Lüscher T \& Vetter W 1981 Twenty-four-hour secretory pattern of cortisol in the bull: evidence of episodic secretion and circadian rhythm. Endocrinology 109 2208-2212.
Veldhuis JD \& Johnson ML 1986 Cluster analysis: a simple, versatile, and robust algorithm for endocrine pulse detection. American Journal of Physiology 250 E486-E493.

Veldhuis JD, Iranmanesh A, Johnson ML \& Lizarralde G 1990 Amplitude, but not frequency, modulation of adrenocorticotropin secretory bursts gives rise to the nyctohemeral rhythm of the corticotropic axis in man. Journal of Clinical Endocrinology and Metabolism 71 452-463.

Veldman RG \& Meinders AE 1996 On the mechanism of alcohol-induced pseudo-Cushing's syndrome. Endocrine Reviews 17 262-268.

Verkerk GA \& Macmillan KL 1997 Adrenocortical responses to an adrenocorticotropic hormone in bulls and steers. Journal of Animal Science 75 2520-2525.

Waas JR, Ingram JR \& Matthews LR 1997 Physiological responses of red deer (Cervus elaphus) to conditions experienced during road transport. Physiology and Behavior 61 931-938.

Walker BR, Best R, Noon JP, Watt GCM \& Webb DJ 1997 Seasonal variation in glucocorticoid activity in healthy men. Journal of Clinical Endocrinology and Metabolism 82 4015-4019.

Ward JR, Henricks DM, Jenkins TC \& Bridges WC 1992 Serum hormone and metabolite concentrations in fasted young bulls and steers. Domestic Animal Endocrinology 9 97-103.

Weitzman ED, Fukushima D, Nogeire C, Roffwarg H, Gallagher TF \& Hellman L 1971 Twenty-four hour pattern of the episodic secretion of cortisol in normal subjects Journal of Clinical Endocrinology and Metabolism 33 14-22.

Yanovski JA, Yanovski SZ, Gold PW \& Chrousos GP 1997 Differences in corticotropin-releasing hormone-stimulated adrenocorticotropin and cortisol before and after weight loss. Journal of Clinical Endocrinology and Metabolism 82 1874-1878.

Received 29 June 1998

Revised manuscript received 22 January 1999

Accepted 7 April 1999 